\title{
Construction Safety Forecast For ITER
}

\section{7th ANS Topical Meeting on the Technology of Fusion Energy}

\author{
L. C. Cadwallader
}

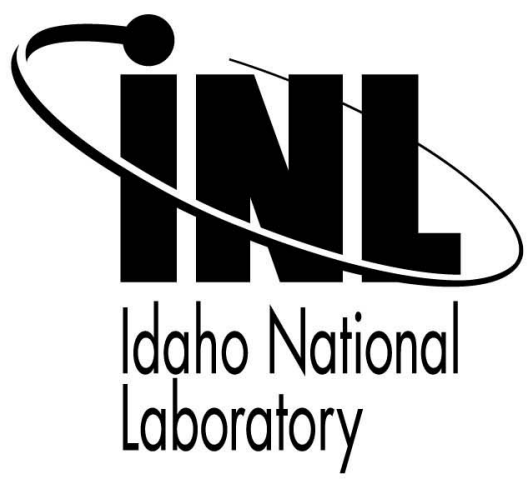

This is a preprint of a paper intended for publication in a journal or proceedings. Since changes may be made before publication, this preprint should not be cited or reproduced without permission of the author. This document was prepared as an account of work sponsored by an agency of the United States Government. Neither the United States Government nor any agency thereof, or any of their employees, makes any warranty, expressed or implied, or assumes any legal liability or responsibility for any third party's use, or the results of such use, of any information, apparatus, product or process disclosed in this report, or represents that its use by such third party would not infringe privately owned rights. The views expressed in this paper are not necessarily those of the United States Government or the sponsoring agency. 


\title{
CONSTRUCTION SAFETY FORECAST FOR ITER
}

\author{
L. C. Cadwallader \\ Idaho National Laboratory, PO Box 1625, Idaho Falls, ID 83415-3860 \\ Lee.Cadwallader@inl.gov
}

\begin{abstract}
The International Thermonuclear Experimental Reactor (ITER) project is poised to begin its construction activity. This paper gives an estimate of construction safety as if the experiment was being built in the United States. This estimate of construction injuries and potential fatalities serves as a useful forecast of what can be expected for construction of such a major facility in any country. These data should be considered by the ITER International Team as it plans for safety during the construction phase. Based on average U.S. construction rates, ITER may expect a lost workday case rate of $<4.0$ and a fatality count of 0.5 to 0.9 persons per year.
\end{abstract}

\section{INTRODUCTION}

In the U.S., there are two major divisions of construction activity. Light construction refers to jobs such as residential, office, and mercantile buildings; banks; schools; restaurants; and surface streets. Heavy construction typically refers to industrial projects such as refineries, factories, power plants, dams, elevated highways, "skyscrapers," large bridges, and other large structures. With its concrete confinement buildings and heavy equipment, the ITER project is certainly classed as heavy construction. For example, the total weight of the ITER tokamak is estimated to be 60,000 tonnes when assembled. ${ }^{1}$

From a construction perspective, ITER has many features in common with fission reactors, such as building walls that support permanent, high-capacity cranes to place heavy components in the buildings, 2+-m thick biological shielding concrete, concrete confinement buildings, large amounts of pipework for fluid systems, complex arrangements of cable and wiring for power and controls, and high-capacity air handling system equipment. ITER will also share many of the same design features as a nuclear power plant, including a radwaste building, auxiliary equipment building, cooling tower heat rejection equipment, and a large electrical switchyard. ITER will have some specialized features as well, including a cryoplant, a tritium fuel handling and storage building, and its own hot cell facility.
Despite the similarities to other fusion and fission construction projects, data from the overall U.S. construction industry are used in this paper. The U.S. has not built a fission reactor in many years, so no recent construction safety data on such work are available. Construction injury rates have also been decreasing, so data previous to the mid-1990's are not necessarily applicable to current construction work. In addition, some of the larger research projects, such as the major U.S. particle accelerators built in the 1960 s to $1980 \mathrm{~s}$, did experience construction fatalities, and these incidents were very similar to those in the broader U.S. construction industry. For these reasons, U.S. private construction industry data were used in this study. This paper also presents data from other planned tokamaks and other projects similar to the ITER experiment.

\section{DATA COLLECTION}

There are several well-known metrics used in construction safety, three of which are used here. The first is the total recordable case (TRC) rate, which counts injuries and illnesses among full-time workers that resulted in days away from work and are recordable by the U.S. Occupational Safety and Health Administration (OSHA). The TRC rate is often cited as events per 100 workers or per 200,000 labor hours (a typical work year is taken to be 2,000 hours). The count of days begins with the day following the injury or illness.

The second metric, the lost workday case (LWC) rate (now called the days away, restricted, or transferred to another job [DART] case rate), measures the number of injuries or illnesses that caused days away from work, days of restricted work activity, or both. The LWC is a more consequential injury than a first aid type of injury. First aid cases are usually minor injuries (for example, small lacerations or abrasions, insect stings or bites, sprains or strains, and foreign bodies in the eyes). In a first aid case, the worker is away from the job while seeking first aid but can return to work the same day. The LWC count, like the TRC rate, begins with the day following the injury or illness. The LWC rate is also 
measured by events per 100 workers per year. It should be noted that in the U.S. system, only employers with more than ten employees per year must keep an annual log of injuries and illnesses. These are the logs compiled by the U.S. Bureau of Labor Statistics to form industry averages. Therefore, the injury and illness data from companies with fewer than ten employees are not represented in this paper.

The third metric is the construction fatality rate, ${ }^{2}$ which is the annual count of fatality cases directly resulting from injuries sustained in work-related accidents. The fatality rate is given per 100,000 employees per year because fatalities are, very fortunately, much more rare events than injuries or illnesses.

Construction worker accidents, or cases, involve several typical types of events that cause injury or fatality: falls, being struck by objects, adverse contact with equipment, highway transportation accidents in performance of work (e.g., delivering materials to job sites), workers being struck by a vehicle or mobile equipment, and exposure to harmful substances. ${ }^{3}$ Accidents or fatalities in commuting to and from work by automobile are not counted in the injury or fatality estimates. Persons suffering from heart attack or other medical conditions are also not counted in injury or fatality estimates unless the condition is proven to be directly caused by accidents occurring in the performance of work (for example, a heart attack due to electrical current exposure, but not a heart attack due to stressrelated factors). This paper focuses on the on-site construction workers rather than the factory and specialty workers who will construct parts to be delivered to the ITER site, or the transportation workers who will ship materials and components to the site from around the world.

The other important piece of information needed in a construction safety forecast is the number of construction workers employed on site. The ITER project has not published the estimated number of workers required on site, but an unofficial estimate is a construction workforce of 3,000 to 4,000 over the 7 to 8 years of construction activity. The peak workforce will likely be on site after the civil construction of the multiple buildings is nearing completion. Then, as the number of concrete fabrication workers is decreasing, the number of special craftsmen will increase to assemble the tokamak and systems inside the buildings (e.g., welders, pipe fitters, electricians, mechanics, and other craftsmen). For nuclear fission power plant construction, workforce estimates have been expressed as 16,000 to 32,000 total man-hours per MWe.
Thus, for a 1,000 MWe fission power plant, a 5-year construction period, and a 2,000-hour worker year, the average annual workforce would be 1,600 to 3,200 workers. Given that ITER will have a tokamak building that is larger than a fission power plant containment building, a cryoplant, a tritium fuel confinement building, and a heavily shielded hot cell facility, ITER is expected to use a larger workforce than a fission reactor construction project. Thus, an estimate of 3,000 to 4,000 workers over the 7 to 8 years of ITER construction is considered to be a reasonable value at present.

\section{ESTIMATES OF CONSTRUCTION WORKER ACCIDENTS}

Tables I and II show injury and illness data for U.S. construction workers compiled from Bureau of Labor Statistics data. ${ }^{5}$ In Table I, the LWC rate for all types of construction have decreased in the 12 years shown, from a high value of 5.4 down to 3.4 , and heavy construction (besides buildings - meaning elevated roads, dams, and other structures such as refineries and airports) decreased from a high value of 4.9 to 3.1. Thus, the U.S. construction industry overall has been improving.

Table II shows that the fatality rate has decreased for the overall U.S. construction industry while the annual employment has increased by over $40 \%$ in the twelve most recent years of data shown. However, the heavy construction industry (for construction other than buildings) has grown about $25 \%$ in employment but has not substantially decreased its fatality rate over the same time period. This discrepancy between typical construction and heavy construction should be taken into account for the ITER construction activity.

Table III gives estimates of construction costs and schedules, workforces, and LWC and fatality rates for some fusion and other comparable construction projects as well as an estimate for ITER construction. Note that some large projects were completed without any fatalities and with low LWC rates. The data given in Table III for ITER show an average LWC rate of $<4.0$ (from Table I) and a fatality count of 0.5 to 0.9 per year. These values are based on an average workforce of 3,000 multiplied by the 10-year U.S. construction averages in Table II.

It is disquieting that the statistical averages predict the possibility of fatalities during the ITER construction activity, but in general the statistics show that there are, unfortunately, a few fatal accidents in major construction projects. Past construction projects for major U.S. particle accelerator facilities in the 1960's to 1980's experienced a few severe injuries and fatalities, ${ }^{6}$ but the more recent 
TABLE I. U.S. Construction Industry Injury and Illness Occupational Data

\begin{tabular}{|l|c|c|c|c|}
\hline \multirow{2}{*}{ Calendar Year } & \multicolumn{2}{|c|}{$\begin{array}{c}\text { U.S. Private Construction Industry, } \\
\text { All Types of Construction }\end{array}$} & \multicolumn{2}{c|}{$\begin{array}{c}\text { U.S. Private Construction Industry, } \\
\text { Heavy Construction }\end{array}$} \\
\cline { 2 - 5 } & TRC Rate & LWC Rate & TRC Rate & LWC Rate \\
\hline 1994 & 11.5 & 5.4 & 10.0 & 4.9 \\
\hline 1995 & 10.6 & 4.9 & 9.9 & 4.8 \\
\hline 1996 & 9.9 & 4.5 & 9.0 & 4.3 \\
\hline 1997 & 9.5 & 4.4 & 8.7 & 4.3 \\
\hline 1998 & 8.8 & 4.0 & 8.2 & 4.1 \\
\hline 1999 & 8.6 & 4.2 & 7.8 & 3.8 \\
\hline 2000 & 8.3 & 4.1 & 7.6 & 3.7 \\
\hline 2001 & 8.9 & 4.0 & 7.8 & 4.0 \\
\hline 2002 & 7.1 & 3.8 & 6.4 & 3.7 \\
\hline 2003 & 6.8 & 3.6 & 6.5 & 3.5 \\
\hline 2004 & 6.4 & 3.4 & 5.9 & 3.2 \\
\hline 2005 & 6.3 & 3.4 & 5.6 & 3.1 \\
\hline 10 -year average & 8.1 & 3.9 & 7.4 & 3.8 \\
\hline
\end{tabular}

TABLE II. U.S. Construction Industry Fatality Occupational Data

\begin{tabular}{|l|c|c|c|c|c|c|}
\hline \multirow{2}{*}{ Calendar Year } & \multicolumn{3}{|c|}{ U.S. Private Construction Industry, } & \multicolumn{3}{c|}{$\begin{array}{c}\text { U.S. Private Construction Industry, } \\
\text { Heavy Construction }\end{array}$} \\
\cline { 2 - 7 } & $\begin{array}{c}\text { Number of } \\
\text { Workers } \\
\left(\times 10^{3}\right)\end{array}$ & $\begin{array}{c}\text { Annual } \\
\text { Fatality } \\
\text { Count }\end{array}$ & $\begin{array}{c}\text { Annual Fatality Rate } \\
\text { per } \\
100,000 \text { Workers }\end{array}$ & $\begin{array}{c}\text { Number of } \\
\text { Workers } \\
\left(\times 10^{3}\right)\end{array}$ & $\begin{array}{c}\text { Annual } \\
\text { Fatality } \\
\text { Count }\end{array}$ & $\begin{array}{c}\text { Annual Fatality Rate } \\
\text { per } \\
100,000 \text { Workers }\end{array}$ \\
\hline 1994 & $5,010.0$ & 1,028 & 20.5 & 736.4 & 246 & 33.4 \\
\hline 1995 & $5,088.1$ & 1,055 & 20.7 & 748.9 & 246 & 32.8 \\
\hline 1996 & $5,359.7$ & 1,047 & 19.5 & 770.7 & 248 & 32.2 \\
\hline 1997 & $5,637.1$ & 1,107 & 19.6 & 791.9 & 252 & 31.8 \\
\hline 1998 & $5,949.5$ & 1,174 & 19.7 & 827.9 & 272 & 32.9 \\
\hline 1999 & $6,337.3$ & 1,191 & 18.8 & 860.0 & 280 & 32.6 \\
\hline 2000 & $6,623.0$ & 1,155 & 17.4 & 890.0 & 284 & 31.9 \\
\hline 2001 & $6,773.5$ & 1,226 & 18.1 & 907.6 & 267 & 29.4 \\
\hline 2002 & $6,683.5$ & 1,125 & 16.8 & 895.6 & 246 & 27.5 \\
\hline 2003 & $6,672.4$ & 1,171 & 17.5 & 891.5 & 286 & 32.1 \\
\hline 2004 & $6,916.4$ & 1,278 & 18.5 & 895.0 & 262 & 29.3 \\
\hline 2005 & $7,166.6$ & 1,238 & 17.3 & 921.5 & 291 & \\
\hline 10 -year average & & & 18.3 & & & 31.6 \\
\hline
\end{tabular}

statistical trends show fewer of these unfortunate events because of industry improvements in safety performance. It should be noted that European Union occupational accident and fatality rates are typically slightly lower than those in the U.S.; ${ }^{7}$ this fact could contribute an immediate small reduction to the suggested ITER values given in Table III.

It is possible that, with good safety management processes, the ITER construction team can keep the LWC rates and fatality counts to values much less than the averages suggested in Table III. First and foremost, ITER management must demonstrate their commitment to safety, which includes planning and funding safety during construction. Next, selecting construction companies with good experience in heavy construction projects and safety performance records better than average will reduce accidents and fatalities. Overall, these approaches are cost effective because of the reduced numbers of accidents, more efficient construction work, and higher employee morale. Safe contractors tend to do better work, they work more efficiently and produce higher quality. 
TABLE III. Construction Project Estimates

\begin{tabular}{|c|c|c|c|c|c|c|}
\hline Project Name & $\begin{array}{l}\text { Overall } \\
\text { Project } \\
\text { Cost } \\
(\$ B)\end{array}$ & $\begin{array}{l}\text { Construction } \\
\text { Time } \\
\text { (yr) }\end{array}$ & $\begin{array}{c}\text { Average } \\
\text { Annual } \\
\text { Workforce } \\
\text { Count }\end{array}$ & $\begin{array}{c}\text { Peak } \\
\text { Annual } \\
\text { Workforce } \\
\text { Count }\end{array}$ & $\begin{array}{l}\text { LWC Rate } \\
\text { (/yr) }\end{array}$ & $\begin{array}{c}\text { Fatality } \\
\text { Count } \\
\text { (/yr) }\end{array}$ \\
\hline $\begin{array}{l}\text { Compact Ignition } \\
\text { Tokamak }^{\mathrm{a}}\end{array}$ & 0.350 & 4 & 108 & 108 & 0.02 & 0 \\
\hline $\begin{array}{l}\text { Tokamak Physics } \\
\text { Experiment }\end{array}$ & 0.500 & 4 & 80 & 150 & 0.06 & 0 \\
\hline $\begin{array}{l}\text { National Spherical Torus } \\
\text { Experiment }^{c}\end{array}$ & 0.025 & 1997-1999 & 20 & 20 & 0.04 & 0 \\
\hline $\begin{array}{l}\text { National Compact } \\
\text { Stellarator Experiment }\end{array}$ & 0.075 & 2006-2009 & 30 & 30 & 0.015 & 0 \\
\hline $\begin{array}{l}\text { Weston 4, Wisconsin } \\
\text { (500 MWe Coal-fired } \\
\text { Power Plant })^{\mathrm{e}} \\
\end{array}$ & 0.752 & 2004-2008 & 1,000 & 1,250 & Goal $^{f}$ is 1.1 & Goal is 0 \\
\hline $\begin{array}{l}\text { Springerville, Arizona } \\
\text { (400 MWe Coal-fired } \\
\text { Power Plant) }\end{array}$ & 0.585 & 2003-2006 & 1,000 & 1,200 & 1.0 & 0 \\
\hline $\begin{array}{l}\text { Spallation Neutron } \\
\text { Source, Tennessee }\end{array}$ & 1.4 & 1999-2006 & 261 & 599 & $\begin{aligned} \text { DART } & =0.9 \\
\text { TRC } & \approx 3.6\end{aligned}$ & 0 \\
\hline $\begin{array}{l}\text { ITER, }{ }^{\mathrm{i}} \text { using U.S. } \\
\text { Construction Averages }\end{array}$ & 10 & 8 & 3,000 est. & 4,000 est. & $<4.0$ est. & $0.5-0.9$ est. \\
\hline \multicolumn{7}{|c|}{$\begin{array}{l}\text { a. Compact Ignition Tokamak major radius }=2.1 \mathrm{~m} \text {. Source: Ref. } 9 \\
\text { b. Tokamak Physics Experiment major radius }=2.25 \mathrm{~m} \text {. Source: Ref. } 10 \\
\text { c. National Spherical Torus Experiment major radius }=0.85 \mathrm{~m} \text {. Source: Ref. } 11 \\
\text { d. National Compact Stellarator Experiment plasma major radius }=1.4 \mathrm{~m} \text {. Source: Ref. } 12 \\
\text { e. Source: Ref. } 13 \\
\text { f. The goal was set at } 50 \% \text { of the Wisconsin State average of } 2.2 . \\
\text { g. Sources: Refs. } 14 \text { and } 15 \\
\text { h. Source: Ref. } 16\end{array}$} \\
\hline
\end{tabular}

\section{CONCLUSIONS}

As ITER moves into the construction activity phase, a forecast of construction worker safety will be a consideration for the host team and the international team. This paper has presented some recent average values from the U.S. construction industry that can be applied to a near-term construction project such as ITER. The statistical averages show a lost workday case rate of $<4.0$ and a fatality count of 0.5 to 0.9 persons per year could be realized if ITER were an average U.S. construction project. It is noted that U.S. rates tend to be slightly higher than European rates, and that some large U.S. construction projects have had very low rates of injuries and no fatalities. Some of the possible steps to reduce these average values are to make a project-level commitment to safety during construction, and to hire companies with above-average heavy construction safety performance to construct the ITER facility.

\section{ACKNOWLEDGMENTS}

This work was prepared for the U. S. Department of Energy, Office of Fusion Energy Sciences, under DOE Idaho Field Office contract number DE-AC07-05ID14517.

\section{REFERENCES}

1. V. A. CHUYANOV, "ITER Plant Layout and Site Services," Nuclear Fusion, 40, 495 (2000).

2. D. A. HEBERLE, Construction Safety Manual, Ch. 3, McGraw-Hill, New York (1998).

3. NATIONAL SAFETY COUNCIL, National Safety Council Injury Facts, 2005-2006 Edition, National Safety Council, Itasca, Illinois (2006).

4. G. W. HINMAN and T. C. LOWINGER, "A Comparative Study of Japan and United States Nuclear Enterprise: Industry Structure and 
Construction Experience," Energy Systems and Policy, 11, 205 (1987).

5. U.S. DEPARTMENT OF LABOR, "Bureau of Labor Statistics," http://www.bls.gov/, Last updated October 27 (2006).

6. L. C. CADWALLADER, Occupational Safety Review of High Technology Facilities, INEEL/EXT05-02616, Idaho National Laboratory (2005).

7. F. G. BENAVIDES, G. L. DELCLOS, S. P. COOPER, and J. BENACH, "Comparison of Fatal Occupational Injury Surveillance Systems Between the European Union and the United States," American Journal of Industrial Medicine, 44, 385 (2003).

8. R. E. LEVITT and N. M. SAMELSON, Construction Safety Management, second edition, Ch. 2, John Wiley \& Sons, Inc., New York (1993).

9. U.S. DEPARTMENT OF ENERGY, Environmental Assessment, The Compact Ignition Tokamak Project at the Princeton Plasma Physics Laboratory, DOE/EA-0333 (draft), U.S. Department of Energy, Washington, D.C. (1989)

10. U.S. DEPARTMENT OF ENERGY, Environmental Assessment, The Tokamak Fusion Test Reactor Decontamination and Decommissioning Project and the Tokamak Physics Experiment at the Princeton Plasma Physics Laboratory, DOE/EA-0813, U.S. Department of Energy, Washington, D.C. (1994).

11. U.S. DEPARTMENT OF ENERGY, Environmental Assessment, The National Spherical Tokamak Experiment at the Princeton Plasma Physics Laboratory, DOE/EA-1108, U.S. Department of Energy, Washington, D.C. (1995).
12. U.S. DEPARTMENT OF ENERGY, Environmental Assessment, The National Compact Stellarator Experiment at the Princeton Plasma Physics Laboratory, DOE/EA-1437, U.S. Department of Energy, Washington, D.C. (2002).

13. U.S. DEPARTMENT OF LABOR, "Weston 4 Partnership Partnering Agreement between United States Department of Labor Occupational Safety and Health Administration (OSHA) and Wisconsin Public Service Corporation (WPSC)," http://www.osha.gov/ desp/partnerships/regional/region5/439_20051026 weston4.html, Last updated January 3 (2006).

14. BECHTEL CORPORATION, "Bechtel BriefsComeback for Coal," http://www.bechtel.com/Briefs/ 0305/Springerville.htm, Last visited November 6 (2006).

15. TUSCON ELECTRIC POWER, "About TEPSpringerville Generating Station Expansion," http://www.tucsonelectric.com/Company/News/ SGS3/index.asp, Last visited November 6 (2006).

16. D. A. RASMUSSEN, Oak Ridge National Laboratory, "Spallation Neutron Source Safety Data," private communication to L. C. Cadwallader, Idaho National Laboratory, February 6 (2006). 